ISSN 1110-0230

\title{
Induction of Systemic Resistance against Charcoal-Rot of Cowpea Caused by Macrophomina phaseolina using Some Inducer Resistance Chemicals
}

\author{
Abdel-Monaim, M.F. and Atwa, M.A.M \\ Plant Pathology Research Institute, Agricultural Research Center, \\ Giza, Egypt.
}

Gixteen isolates of Macrophomina phaseolina were isolated from the roots of cowpea showing charcoal-rot collected from different locations in New Valley Governorate. All the obtained isolates were able to attack cowpea plants (cv. Balady) causing charcoal rot on the basal stem with various degrees of disease severity. Isolate No. 14 was the most aggressive one in this respect causing $85.8 \%$ charcoal rot. Potassium silicate (KS), propyl gallate (PG), hydroquinone (HQ) and salicylic acid (SA) at 1,5 and $10 \mathrm{mM}$ were used in this investigation as promising inducer resistance chemicals (IRCs) for controlling the disease in vitro and in vivo. Results illustrated that all tested IRCs had little effect on the growth of $M$. phaseolina at different concentrations in vitro. In addition, the inhibition of the growth was slightly increased by increasing the IRCs concentrations. Under greenhouse (New Valley Agric. Res. Station) and field conditions (New Valley Agric. Res. Station at El-Kharga and East Al Owainat Res. Station) all the tested IRCs significantly decreased charcoal rot compared to the check treatment (control). Both PG and HQ were the most efficient ones in decreasing the severity of the disease. On the contrary, both $\mathrm{SA}$ and $\mathrm{KS}$ recorded the lowest protection against charcoal rot severity. Also, all the tested IRCs significantly improved cowpea plant growth parameters, i.e. plant height, No. of branches/plant, fresh and dry weight of plants ( $\mathrm{kg} /$ feddan) and yield components, i.e. pod length $(\mathrm{cm})$, No. of seeds/pod, the weight of 100 seeds, total seed yield $(\mathrm{Kg} /$ feddan) compared with control during summer season 2017. Cowpea seeds soaked in PG at $5 \mathrm{mM}$ recorded the highest growth and yield components in both locations. While HQ recorded the lowest ones. Analysis of plant mineral compositions showed a significant increase in contents of nitrogen $(\mathrm{N})$, potassium $(\mathrm{K})$, phosphorus $(\mathrm{P})$ and crude protein in cowpea plants raised from cowpea seeds treated with any of the tested IRCs compared with control plants during growing summer season 2017. The highest increase was obtained for these mineral contents when cowpea seeds were soaked in SA except for potassium in East Al Owainat. While, KS treatment recorded the lowest plant mineral contents of estimated minerals in both locations, except for potassium in East $\mathrm{Al}$ Owainat.

The activation of peroxidase (PO), polyphenoloxidase (PPO), phenylalanine ammonia-lyase (PAL), pathogenesis-related protein 
(chitinase and $\beta-1,3$ glucanase) and phenolic contents in inoculated plants with $M$. phaseolina treated with the IRCS were increased compared with untreated inoculated plants and untreated uninoculated plants. PG recorded the highest levels of oxidative enzymes, pathogenesis-related (PR) protein and phenol contents during all tested periods of determination. In general, enzymes activities of PO, PPO $\beta-1,3$ glucanase and chitinase begin to accumulate after two days of treatment and reached maximum levels at 8 days while PAL reached maximum level at 6 days then decreased progressively. On the other hand, total phenols increased in cowpea plants inoculated with $M$. phaseolina and treated tested IRCS. The highest accumulation of phenols was recorded 6 days after the application.

Keywords: Cowpea, charcoal-rot, induce resistance, plant minerals, oxidative-reductive enzymes, total phenols, growth and crop parameters

Cowpea, Vigna unguiculata (L.) Walp. is one of the most important food and forage legumes in the semi-arid regions. It can fix atmospheric nitrogen in the soil at the rate of $56 \mathrm{~kg}$ per ha in association with symbiotic bacteria and contributes to soil fertility improvement particularly in smallholder farming systems where little or no fertilizer is used (Kyei-Boahen et al., 2017and Mohanapriya et al., 2017)

Cowpea provides considerable protein (Singh and Rachie, 1985) and as a food legume it constitutes the natural protein supplement to staple diets, and represents the legume of choice for many populations in Africa (Bliss, 1975). It is often called "meat for poor people", since this protein is the cheapest (Adandonon , 2004).

Cowpea is liable to attacks by many soil-borne fungal diseases (Adegbite and Amusa, 2010). In addition, charcoal-rot caused by Macrophomina phaseolina (Tassi) Goid. (the pycnidial state of Sclerotium bataticola Taub.) is one of the most destructive diseases in tropic and subtropic areas (Dhingra and Sinclair 1977; Reuveni et al., 1983 and Adegbite and Amusa, 2010).

The information on worldwide losses caused by charcoal rot of cowpea is not available, but there is no doubt that the disease is of increasing importance and has the potential to cause destruction in susceptible cowpea cultivars, especially in the conditions of high temperature and soil water stress. Since the high temperatures and drought stress that accompany climate change will provide more favorable conditions for M. phaseolina (Smith and Wyllie, 1999). However, In the Sahelian zone of West Africa, charcoal rot is estimated to cause a yield loss of $10 \%$ of cowpea (Ndiaye, 2007).

An investigation for controlling cowpea charcoal rot is considered important, epically because of its prevalence in Egypt, particularly in newly reclaimed land in

Egypt. J. Phytopathol., Vol. 47, No. 1 (2019) 
the desert. However, the wide host range exhibited by this pathogen complicates management strategies. Soil solarization and chemical control of the disease is difficult and economically not affordable for low-income small scale farmers (Afouda et al., 2012). Even though a few resistant cultivars have been recorded, they often showed partial levels of resistance (Demooy et al., 1989) and are not obtainable to the farmers. Much of the effort to control M. phaseolina has focused on chemical usage and soil fumigation (Pearson et al., 1984). Other recommended control practices include biological control of $M$. phaseolina, antagonistic bacteria and fungi that have been investigated (Afouda et al., 2012, Karthikeyan et al., 2015 and Khalili et al., 2016). The reduction in the availability of effectively approved fungicides due to health and environmental concerns and resistance development in target pathogens (Kuck and Gisi, 2007) exhibit the necessity of increasing research to development of novel, effective and sustainable disease control solutions. Therefore, induced resistance could be proposed as an alternative, non-conventional and ecologically-friendly approach for plant protection.

The protection afforded by systemic acquired resistance (SAR) is frequently non-specific and long-lasting (Kessmann et al., 1994). Systemic acquired resistance against pathogens can be induced by several synthetic chemical agents, such as salicylic acid, benzothiadiazole, $\beta$-aminobutyric acid, chitosan, and so forth which affect the production of phenolic compounds and increase the activity of various defense-related proteins. (Zakir, 2018). Salicylic acid (SA) was the first synthetic compound shown to induce enhanced activation of a variety of defense responses against major pathogens on various crops (Thakur and Sohal, 2013). Tested antioxidants included propylgallate reduced damping-off, root rot/wilt and area under root rot/wilt progress curve in pepper plants when used as seed soaking, seedling soaking, and soil drench under greenhouse and field conditions (AbdelMonaim and Ismail, 2010). Moreover, propylgallate as either seed soaking or soil drenching proved sufficient protection against cumin wilt caused by $F$. oxysporum $\mathrm{f}$. sp. cumini (Mostafa, 2006). However, Hydroquinone (HQ) is an aromatic organic compound that is a type of phenol, this phenol can act as an antioxidant. It was reported to inhibit some pathogenic fungi as well as improving the growth and yield of peanut (Elwakil, 2003); alfalfa (Al-Askar et al., 2013); Jerusalem Artichoke plants (Al-Askar et al., 2014 \& Ezzat et al., 2015). On the other side, silicon (Si) is known to effectively mitigate various environmental stresses and enhances plant resistance against both fungal and bacterial pathogens, silicon has been reported to prevent the incidence of powdery mildew diseases, in several plant species, for example, in barley, cucumber, melon, pumpkin, rose and wheat (Wang et al., 2017). In addition to blast and powdery mildew, the occurrence of soil-borne fungal diseases, such as crown and root rot of cucumber (Chérif et al., 1994); root rot of tomato (Heine et al., 2007); Phytophthora blight of bell pepper (French-Monar et al., 2010); Fusarium crown and root rot of tomato (Huang et al., 2011); Phytophthora stem and root rot of soybean (Guérin et al., 2014); root rot and wilt diseases of 
fodder beet (Abdel-Monaim et al., 2015) and Fusarium wilt of cotton (Whan et al., 2016) were also suppressed by Si application.

The present research focuses on studying the effect of salicylic acid, propyl gallate, potassium silicate, hydroquinone as inducer chemicals against the charcoal disease of cowpea either in vitro or in vivo as well as its influence on plant growth and yield components in the field. Also, biochemical changes associated with the application of these inducer chemicals were assessed.

\section{Materials and Methods}

Isolation, purification, and identification of the pathogen:

The fungus was isolated from cowpea plants infected by charcoal rot disease collected from different locations of New Valley Governorate. Infected plant tissues bearing fungal sclerotia were selected and washed under the tap water, then cut into small pieces $(5-10 \mathrm{~mm})$ along with a healthy portion. These pieces were surface sterilized by dipping in $1 \% \mathrm{NaOCl}$ solution for about 2 minutes followed by thoroughly three consecutive washing with sterilized water, then drying with a sterile paper towel. The sterilized pieces were transferred to potato dextrose agar (PDA) medium amended with ampicillin $(200 \mathrm{mg} / \mathrm{L})$ then incubated at $28 \pm 2{ }^{\circ} \mathrm{C}$ for 5 days. Purification of the isolated fungus was carried out on plain agar medium using hyphal tip transfer onto fresh PDA media as described by Dhingra and Sinclair (1985). The isolated fungus was identified according to their morphological characters according to Sutton (1980) and Phillips et al. (2013). Subcultures of the obtained isolates were then kept on PDA slants and stored at $4 \pm^{\circ} \mathrm{C}$ for further studies.

\section{Preparation of fungal inoculum:}

A- Solid medium:

The inoculum of $M$. phaseolina was prepared by growing the fungus in glass bottles $500 \mathrm{ml}$ containing sterilized sorghum medium (100 $\mathrm{g}$ of sorghum grains and $90 \mathrm{ml}$ of water). The bottles were inoculated with five mycelial plugs $(6 \mathrm{~mm}$ in diameter) cut from the margin of a 4-day-old colony growing on PDA and incubated at $28 \pm 2^{\circ} \mathrm{C}$ for 18 days until sorghum grain completely colonized with microsclerotia. The incubated bottles were shaken at alternate days for uniform colonization of the grains. The colonized sorghum grains were air-dried for $48 \mathrm{~h}$ and ground to coarse particles and then used.

\section{B- Liquid medium:}

The inoculum of $M$. phaseolina was prepared from two weeks old culture grown in $100 \mathrm{ml}$ potato dextrose $(\mathrm{PD})$ broth medium in flasks $(500 \mathrm{ml})$ and incubated at $28 \pm 2^{\circ} \mathrm{C}$ according to Muthomi et al. (2007). The content of the flask was homogenized with sterile distilled water in a blender. The sclerotial suspension was diluted to contain $2 \times 10^{3}$ sclerotia/ml water then used for soil infestation.

Egypt. J. Phytopathol., Vol. 47, No. 1 (2019) 
Greenhouse experiments:

Pathogenicity test:

Pathogenicity test of M. phaseolina (16 isolates) was carried out at New Valley Agric. Res. Stat. on cowpea local Balady cultivar. Plastic pots $(30 \mathrm{~cm}$ in diameter) with a bottom drainage hole were sterilized by dipping in 5\% formalin solution for 15 minutes and left for one week until complete formalin evaporation. Pots were filled with steam disinfested sandy clay soil 2:1 (v/v). The inoculum of each isolate was mixed with soil at $2 \%$ by weight at the time of sowing. Sterilized un-inoculated sorghum grains were added to the disinfested soil at the same rate for use as healthy control. Cowpea seeds were surface sterilized by immersing them in $1 \%$ sodium hypochlorite solution for 2 min then washed several times with sterilized water. Five cowpea seeds were sown in each pot and pots were irrigated directly. Five replicated pots were used for each isolate. All pots were irrigated with tap water as required to maintain sufficient soil moisture, and fertigated two weeks after sowing then every week with $0.1 \%$ solution of NPK fertilizer (15:15:15).

Disease-severity rating and incidence:

Forty five days after sowing, cowpea plants were rated for disease severity with a modification of the methods of Mengistu et al. (2007). Diseased plants were rated on a scale of 0-5, based on the percentage of foliage yellowing and inspected of longitudinally splitting of the stem and taproot of each plant gently uprooted, in which $0=$ no symptoms; $1=1-25 \%$ chlorosis of leaves and no microsclerotia visible in tissue; $2=26-50 \%$ chlorosis of leaves and very few microsclerotia visible under the epidermis; $3=51-75 \%$ chlorosis of leaves, the vascular tissue is partly discolored and little microsclerotia visible in tissue; $4=$ more than $75 \%$ chlorosis of leaves and vascular tissue is discolored with numerous microsclerotia embedded in the tissue; $5=$ completely dead plants. The disease severity (\%) was calculated using the following formula:

Where:

$$
\text { Disease severity }(\%)=\sum(\mathrm{n} \times \mathrm{v}) / 5 \mathrm{~N} \times 100
$$

$\mathrm{n}=$ number of plants in each category

$\mathrm{v}=$ numerical values of scale symptoms category

$\mathrm{N}=$ the total number of numerical values of symptoms categories.

Effect of inducer resistance chemicals (IRCs) on the linear growth of the causal fungus in vitro

The inducer resistance chemicals (IRCs), i.e. propyl gallate, potassium silicate, hydroquinone, and salicylic acid were used separately at concentrations 1, 5 and 10 $\mathrm{mM}$ for studying their effect on linear growth of M. phaseolina. Mycelium disks (5 $\mathrm{mm}$ in diameter) taken from the growing edge of 4-day-old cultures of $M$. phaseolina were transferred to Petri-plates containing $20 \mathrm{ml}$ sterilized Czpeck's solid medium amended with each concentration of each IRCs. IRCs free medium was 
served as control. All plates were incubated at $28 \pm 2{ }^{\circ} \mathrm{C}$ until the Petri-plates in the control treatment were fully covered with mycelial growth (5 days). Four replicates were used for each treatment. The inhibition percentage of radial growth was calculated using the following formula:

Where:

Inhibition of radial growth $(\%)=(\mathrm{D} 1-\mathrm{D} 2) / \mathrm{D} 1 \times 100$

$\mathrm{D} 1=$ Colony diameter in the control

D2 $=$ Colony diameter in treatment.

Effectiveness of IRCs for controlling charcoal rot under greenhouse conditions:

As in the pathogenicity test, sterilized plastic pots were filled with steam disinfested sandy clay soil. The inoculum of highly virulent isolate (No.14) was mixed with soil at $2 \%$ inoculum level at the time of sowing. The cowpea seeds were soaked in K- silicate, propyl gallate, hydroquinone and salicylic acid at different concentrations $(1,5$ and $10 \mathrm{mM})$ for $6 \mathrm{hr}$. In the control treatment, seeds were soaked in water for the same time. Five cowpea seeds were sown in each pot and five replicated pots were used for each treatment. Disease severity (\%) was calculated after 45 days from seeding as mentioned before.

Biochemical changes in cowpea plants treated with the inducer resistance chemicals:

The activity of peroxidase, polyphenoloxidase (PPO), phenylalanine ammonialyase (PAL), pathogenesis-related protein (chitinase and $\beta-1,3$ glucanase) and phenolic content was estimated. As in the pathogenicity test, sterilized plastic pots were filled with steam disinfested sandy clay soil. Surface sterilized cowpea seeds were sown and fifteen days later, seedlings were injected with $50 \mu 1 /$ plant of Ksilicate, propyl gallate, hydroquinone, salicylic acid at $5 \mathrm{mM}$ and sterilized distilled water (SDW) by sterile syringe at the base of the stem (Saikia et al., 2006). After 2 days of treatments, pots were inoculated with $100 \mathrm{~mL}$ of M. phaseolina homogenate suspension $2 \times 10^{3}$ sclerotia/ml water per pot. The following treatments were made (1) Control- treated with SDW only; (2) Control treated with M. phaseolina; (3) Treatment with K- silicate; (4) Treatment with propyl gallate; (5) Treatment with hydroquinone and (6) Treatment with salicylic acid. The activity of the enzymes and phenolic content was estimated after 0,2, 4, 6, 8 and 10 days post inoculation

Assessment the activity of oxidative and pathogenesis-related protein enzymes:

One gram of plant tissue was homogenized in $10 \mathrm{ml}$ of ice-cold $50 \mathrm{mM}$ potassium phosphate buffer $(\mathrm{pH} 6.8)$ containing $1 \mathrm{M} \mathrm{NaCl}, 1 \%$ polyvinylpyrrolidone (PVP), $1 \mathrm{mM}$ EDTA and $10 \mathrm{mM} \beta$-mercaptoethanol (Biles and Martyn, 1993). After filtration through cheesecloth, the homogenates were centrifuged at $8000 \mathrm{rpm}$ at $4^{\circ} \mathrm{C}$ for $25 \mathrm{~min}$. The supernatants (crude enzyme extract) were stored at $-20^{\circ} \mathrm{C}$ or immediately used for determination of $\mathrm{PO}$ according to to Chakraborty \& Chatterjee (2007), PPO (Gauillard et al., 1993), PAL (Cavalcanti et al., 2007), and pathogenesis-related protein, chitinase, and $\beta$ - 1,3-glucanase enzymes activities

Egypt. J. Phytopathol., Vol. 47, No. 1 (2019) 
according to Wirth and Wolf (1992) and Pan et al., (1991), respectively. In the case of every enzyme under investigation, each treatment consisted of four replicates ( 3 plants/ replicate) and two spectrophotometric readings using Milton Roy Spectrophotometer (Milton Roy Spectronic 1201) were taken per replicate.

Estimation of phenolic contents:

The total phenol contents were quantified by the Folin-Ciocalteau phenol reagent according to the protocol of $\mathrm{Xu}$ and Chang (2007). The standard curve was prepared using known concentrations of gallic acid (GAE). The total phenol content in the test samples was calculated from the Gallic acid standard curve. The amount of phenolic content was expressed as phenol equivalents in $\mathrm{mg} / \mathrm{gm}$ fresh tissue.

Field experiments:

The experiment was carried out in the Exp. Farm of New Valley Agric. Res. Stat., at El-Khargaand East Al Owainat Stat.ARC during growing summer season 2017 for controlling charcoal rot disease of cowpea in a naturally infested field where both locations have a back history of natural infestation with M. phaseolina.

Cowpea seeds (cv. Balady) were soaked in the tested inducer resistance chemicals at $5 \mathrm{mM}$ for $6 \mathrm{hr}$. In the control treatment, seeds were soaked in only water for the same period. The disinfected cowpea seeds were sown in the field on May 3\&4 2017 for both locations, respectively. The treatments were distributed in a randomized blocks design with four replicates; the experimental plot area was $12 \mathrm{~m}^{2}$ $(4 \times 3 \mathrm{~m})$ containing 10 rows of $3 \mathrm{~m}$ length and $40 \mathrm{~cm}$ width. All recommended agricultural practices were adopted throughout the two locations. Charcoal rot severity was also recorded on a random sample of plants of the plots two months after planting as mentioned before. Also, the averages of plant height, and the number of branches/plant were assessed for twenty randomly plants/ experimental plot. At the same time, half of the plot area was cutting to determine fresh forage yield (ton /feddan) then dry forage yield (ton/feddan) was determined as follows: subsamples of $250 \mathrm{gm}$ each were dried at $70^{\circ} \mathrm{C}$ to constant weight and dry matter percentage was estimated. The dry forage yield (ton /feddan) was calculated by multiplying fresh forage (ton /feddan.) with dry matter percentage DM\% (AbdelAziz et al., 2008). The other half of the experimental plot was left to maturity and the following measurements were estimated; pod length $(\mathrm{cm})$, No. of seed /pod, the weight of 100 seeds and total seed yield (Kg /feddan).

\section{Chemical constitutes:}

The dry plant samples were ground and prepared for wet digestion using $\mathrm{H}_{2} \mathrm{SO}_{4}$ and $\mathrm{H}_{2} \mathrm{O}_{2}$ methods as described by Page et al., (1982). The digests were then subjected to the measurement of nutrients Nitrogen $(\mathrm{N})$, Phosphorus (P), and Potassium (K) (Cottenie et al., 1982). The previously determined nitrogen of dry forage was used for calculating total crude protein (TCP \%) by multiplying $\mathrm{N}$ values by 6.25 . 
Statistical analysis

Completely randomized design (CRD) and randomized blocks design (RBD) were implemented in the greenhouse experiment and field experiment, respectively. The obtained data were subjected to computer statistical software (ASSISTAT) originated by Silva \& Azevedo (2009). Data analyzed using analysis of variance (ANOVA), and mean values were compared using the least significant difference (LSD) at a significance level of $\mathrm{P} \leq 0.05$.

\section{Results}

Isolation of the causal fungus:

Isolation trails from cowpea rotted roots with charcoal-rot collected from different localities of New Valley governorates yielded one fungus only. The fungus was identified as Macrophomina phaseolina (Tassi) Goid (the pycnidial state of Sclerotium bataticola Taub).

Pathogenicty test of sixteen M. phaseolina isolates:

Results illustrated in Fig. (1) show that all the obtained isolates (16 isolates) were able to attack cowpea plants (cv. Balady) causing charcoal rot on the basal stem with various degrees of disease severity, 45 days after inoculation. Isolate 14 caused the highest charcoal rot severity (85.8\%) followed by isolates 4, 10, 9 and 1, being 76.4, 75.4, 72.4 and $64.6 \%$ disease severity, respectively). While the other isolates lower incidence and severity showed.

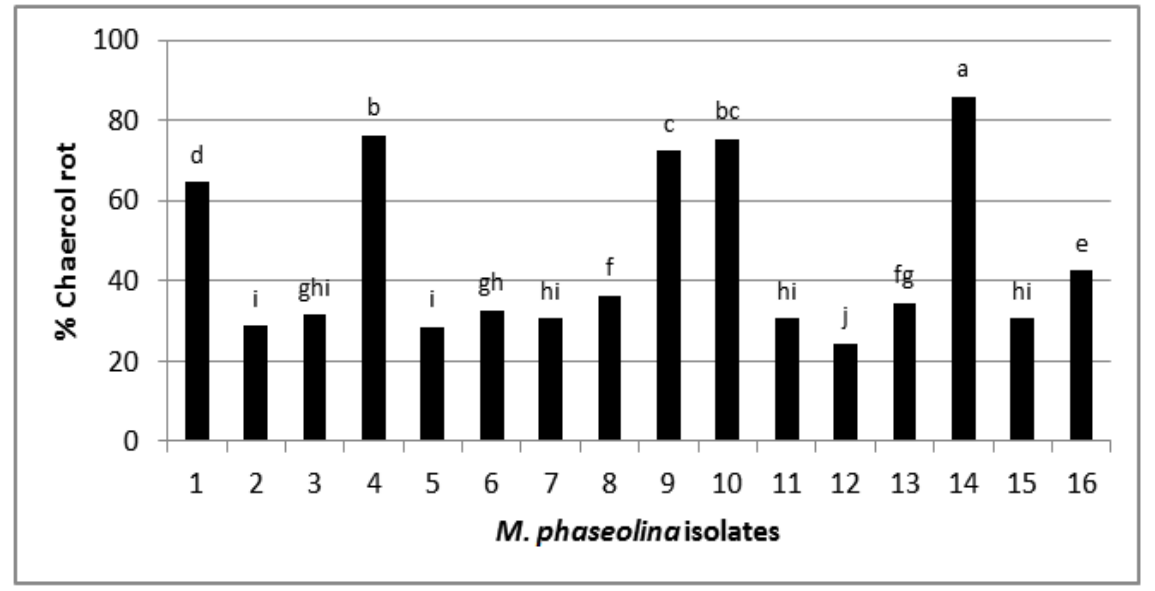

Figure (1): Pathogenicity test of sixteen M. phaseolina isolates isolated from naturally diseased cowpea plants. Columns with the same letter represent values that are not significantly different according to the LSD test $(p \leq 0.05)$.

Egypt. J. Phytopathol., Vol. 47, No. 1 (2019) 
Effect of IRCs on linear growth of $M$. phaseolina in vitro.

Data presented in Table (1) indicate that all tested IRCs, i.e. HQ, KS, PG and SA had little effect on suppression of the linear growth of the causal fungus at different concentrations in vitro. The percentages of linear growth inhibition of M. phaseolina were slightly increased, being 8.53, 10.48 and $12.4 \%$ by increasing the concentration of the inducer resistance chemicals, i.e. 1,5 and $10 \mathrm{mM}$, respectively. HQ recorded the highest inhibitory effect, being $16.17 \%$ followed by SA $10.13 \%$. Both PG and KS recorded the lowest inhibition percentages, being $7.6 \%$ and $7.97 \%$, respectively.

Table (1): Effect of the tested IRCs at different concentrations on the mycelial growth of $M$. phaseolina in vitro, 5 days after incubation at $28 \pm 2{ }^{\circ} \mathrm{C}$.

\begin{tabular}{lcccc}
\hline \multirow{2}{*}{ Treatments } & \multicolumn{5}{c}{ \% Mcelial growth inhibition at (mM) } \\
\cline { 2 - 5 } & $1 \mathrm{mM}$ & $5 \mathrm{mM}$ & $10 \mathrm{mM}$ & Mean \\
\hline Potassium silicate & 6.5 & 8.5 & 8.9 & 7.97 \\
Propyl gallate & 6.5 & 7.4 & 8.9 & 7.60 \\
Hydroquinone & 12.5 & 15.6 & 20.4 & 16.17 \\
Salicylic acid & 8.6 & 10.4 & 11.4 & 10.13 \\
Mean & 8.53 & 10.48 & 12.40 & - \\
\hline LSD at 0.05 & \multicolumn{5}{c}{1.16} \\
Treatments $(\mathrm{A})=$ & \multicolumn{5}{c}{1.00} \\
Concentrations $(\mathrm{B})=$ & \multicolumn{5}{c}{2.00} \\
Interactions $(\mathrm{A} \times \mathrm{B})=$ & \multicolumn{5}{c}{} \\
\hline
\end{tabular}

Effectiveness of IRCs at different concentrations for controlling charcoal-rot under greenhouse conditions:

Data presented in Table (2) show that all tested IRCs at the different concentrations significantly decreased charcoal-rot caused by M. phaseolina in pots compared with control. All the tested IRCs at $5 \mathrm{mM}$ concentration were more effective for decreasing charcoal-rot severity than the lower concentration $(1 \mathrm{mM})$ or higher concentration $(10 \mathrm{mM})$. PG recorded the highest protection against charcoal rot severity followed by $(\mathrm{HQ})$ and $(\mathrm{SA})$, while $(\mathrm{KS})$ gave the lowest protection in this respect. Generally, PG at $5 \mathrm{mM}$ followed by $\mathrm{HQ}$ at $5 \mathrm{mM}$ were the highest effective for decreasing charcoal rot severity, while $\mathrm{KS}$ at $1 \mathrm{mM}$ caused the lowest decrease of charcoal rot severity in pots.

Effect of the tested IRCs on charcoal-rot severity under field conditions:

Results illustrated in Fig. (2) reveal that all tested IRCs significantly decreased charcoal rot disease compared to the control treatment (check) under field conditions in El-Kharga and East Al Owainat Stations during the growing season 2017, respectively. PG and HQ resulted in the lowest charcoal rot severity compared with control treatment in the two locations. However, PG resulted in 26.24 and $19.33 \%$ 
charcoal-rot severity and HQ recorded 27.67 and $22.28 \%$ charcoal-rot severity compared with 45.67 and $38.67 \%$ in control in both locations, respectively. On the contrary, SA and KS recorded the lowest protection against charcoal rot disease in both locations.

Table (2): Effect of the tested IRCs as seed treatment on the severity of charcoal-rot of cowpea plants grown in artificially infested soil with $M$. phaseolina under greenhouse conditions, 45 days after sowing.

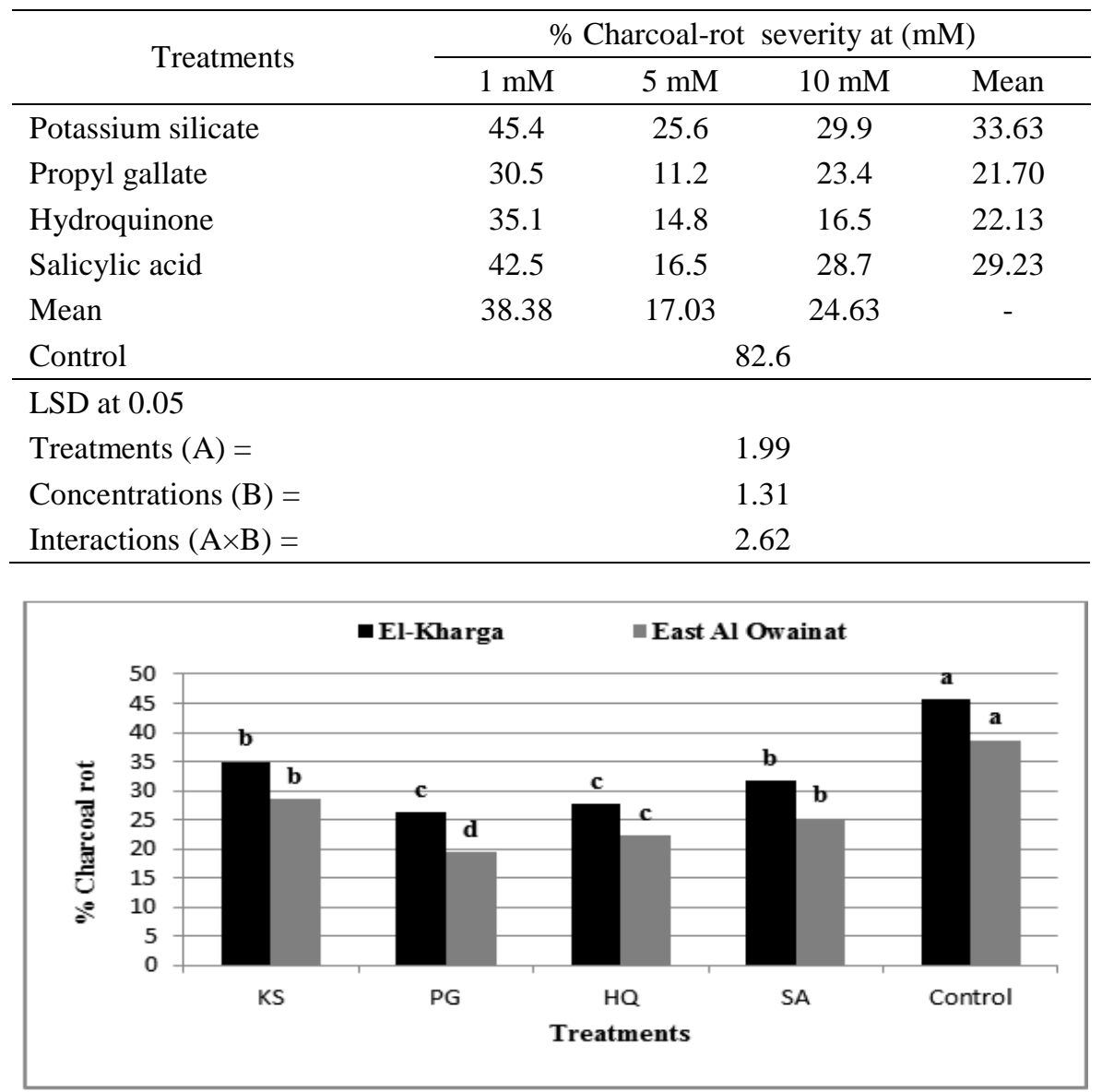

Figure (2): Effect of IRCsas seed treatments on charcoal-rot severity of cowpea plants grown under field conditions (natural infection) at El-Kharga and East Al Owainat Stations during summer growing season 2017.

Egypt. J. Phytopathol., Vol. 47, No. 1 (2019) 
Effect of the tested IRCs on some growth and crop parameters under field conditions:

The effect of soaking cowpea seeds in the tested IRCs on the growth and crop parameters under field conditions at El-Kharga and East Al Owainat Stations during summer season 2017 were assessed. Data in Table (3) indicate that all the tested IRCs significantly improved cowpea plant height $(\mathrm{cm})$, the number of branches /plant, fresh and dry weight of plants (ton/feddan) compared control. soaking cowpea seeds in PG at $5 \mathrm{mM}$ was the most effective treatment, it recorded the highest plant height $(90.0$ and $89.64 \mathrm{~cm})$ and the number of branches $(4.8$ and 5.6 branch/plant) compared with control treatment which recorded 53.25 and $52.34 \mathrm{~cm}$ and 2.5 and 2.7 (branch/plant) in both locations, respectively. Also, PG treatment recorded the highest fresh and dry weights (ton/ feddan), that increased fresh weight from 7.07 and 7.27 ton/ feddan in control treatment to 14.65 and 14.25 ton/ feddan in both locations, respectively. Also, dry weight was increased from 2.15 and 2.12 ton/ feddan in control treatment to 3.75 and 3.72 ton/ feddan in both locations, respectively. On the contrary, soaking cowpea seed soaked in HQ and SA at $5 \mathrm{mM}$ showed no significant differences and were less effective treatments in both locations compared to other rest treatments.

Table (3): Effect of the tested IRCs as seed treatments on some growth parameters of cowpea plants grown under field conditions (natural infection) at El-Kharga and East Al Owainat Stations during summer growing season 2017.

\begin{tabular}{|c|c|c|c|c|}
\hline Treatments & $\begin{array}{l}\text { Plant height } \\
(\mathrm{cm})\end{array}$ & $\begin{array}{l}\text { No. of } \\
\text { Branches/ } \\
\text { plant }\end{array}$ & $\begin{array}{c}\text { Fresh weight } \\
\text { (Ton / } \\
\text { feddan) }\end{array}$ & $\begin{array}{l}\text { Dry Weight } \\
\text { (Ton/ } \\
\text { feddan) }\end{array}$ \\
\hline \multicolumn{5}{|c|}{ El-Kharga } \\
\hline Potassium silicate & 83.15 & 4.0 & 13.63 & 3.34 \\
\hline Propyl gallate & 90.00 & 4.8 & 14.65 & 3.75 \\
\hline Hydroquinone & 75.25 & 4.1 & 12.23 & 2.97 \\
\hline Salicylic acid & 77.25 & 4.5 & 11.48 & 2.88 \\
\hline Control & 53.25 & 2.5 & 7.07 & 2.15 \\
\hline LSD at 0.05 & 4.37 & 0.44 & 1.54 & 0.39 \\
\hline \multicolumn{5}{|c|}{ East Al Owainat } \\
\hline Potassium silicate & 81.49 & 5.2 & 13.43 & 3.28 \\
\hline Propyl gallate & 89.64 & 5.6 & 14.25 & 3.72 \\
\hline Hydroquinone & 72.48 & 4.8 & 11.86 & 2.84 \\
\hline Salicylic acid & 75.69 & 5.0 & 11.00 & 2.76 \\
\hline Control & 52.34 & 2.7 & 7.27 & 2.12 \\
\hline LSD at 0.05 & 4.84 & 0.57 & 2.23 & 0.30 \\
\hline
\end{tabular}


Data presented in Table (4) indicate that all tested IRCs significantly increased weight of 100 seeds and total seed weight $\mathrm{Kg}$ / feddan compared with control in both locations during the growing season 2017. Cowpea seeds soaked in PG at $5 \mathrm{mM}$ recorded the highest value of all yield components in both locations. While HQ treatment was recorded the lowest seed yield at the two locations.

Table (4): Effect of the tested IRCs as seed treatments on some crop parameters of cowpea plants grown under field conditions (natural infection) at ElKharga and East Al Owainat Stations during summer growing season 2017.

\begin{tabular}{lcccc}
\hline \multicolumn{1}{c}{ Treatments } & $\begin{array}{c}\text { Pod length } \\
(\mathrm{cm})\end{array}$ & $\begin{array}{c}\text { No. of seed/ } \\
\text { pod }\end{array}$ & $\begin{array}{c}\text { Weight of } \\
100 \text { seeds }\end{array}$ & $\begin{array}{c}\text { Total seed } \\
\text { yield (Kg/ } \\
\text { feddan) }\end{array}$ \\
\hline Potassium silicate & 18.2 & 12.8 & 7 & 589.6 \\
Propyl gallate & 18.6 & 13.2 & 7.4 & 625.5 \\
Hydroquinone & 17.1 & 12.4 & 6.8 & 536.8 \\
Salicylic acid & 17.4 & 12.5 & 6.9 & 555.4 \\
Control & 15.7 & 10.1 & 5.2 & 302.14 \\
LSD at 0.05 & 2.27 & 1.76 & 1.56 & 22.24 \\
\hline & & East Al Owainat & & \\
Potassium silicate & 17.9 & 12.4 & 7.2 & 558.8 \\
Propyl gallate & 17.5 & 13.0 & 7.5 & 602.0 \\
Hydroquinone & 16.8 & 12.0 & 6.9 & 513.6 \\
Salicylic acid & 16.5 & 11.9 & 6.8 & 542.2 \\
Control & 14.5 & 9.6 & 5.1 & 288.3 \\
LSD at 0.05 & 3.09 & 2.62 & 1.40 & 17.85 \\
\hline
\end{tabular}

Mineral contents:

Analysis of plant mineral compositions showed a significant increase in nitrogen $(\mathrm{N})$, potassium $(\mathrm{K})$, phosphorus $(\mathrm{P})$, and crude protein in plants raised from cowpea seeds treated with any of the tested IRCs compared with control plants in both locations (Table 5). The highest increase was obtained for these mineral contents when cowpea seeds were soaked in SA except for $\mathrm{K} \%$ in East Al Owainat. While, KS treatment recorded the lowest plant mineral contents of all tested minerals in both locations, except for $\mathrm{K} \%$ in East Al Owainat which ranked the second.

Egypt. J. Phytopathol., Vol. 47, No. 1 (2019) 
Table (5): Effect of the tested IRCs as seed treatments on nitrogen (\%), potassium (\%), phosphorus $(\%)$, and crude protein $(\%)$ of cowpea plants grown under field conditions (natural infection) at El-Kharga and East Al Owainat Stations during summer growing season 2017.

\begin{tabular}{lcccc}
\hline \multirow{2}{*}{ Treatments } & \multicolumn{4}{c}{ \% Contents of } \\
\cline { 2 - 5 } & $\mathrm{N}$ & $\mathrm{K}$ & $\mathrm{P}$ & Protein \\
\hline \multirow{2}{*}{ El-Kharga } & & \\
Potassium silicate & 4.10 & 2.11 & 0.26 & 25.63 \\
Propyl gallate & 4.32 & 2.23 & 0.33 & 27.00 \\
Hydroquinone & 4.21 & 2.32 & 0.28 & 26.31 \\
Salicylic acid & 4.35 & 2.36 & 0.36 & 27.19 \\
Control & 3.01 & 1.09 & 0.18 & 18.81 \\
LSD at 0.05 & 0.40 & 0.23 & 0.05 & 2.50 \\
\hline & East Al Owainat & & \\
Potassium silicate & 3.88 & 2.21 & 0.24 & 24.25 \\
Propyl gallate & 4.11 & 2.05 & 0.27 & 25.69 \\
Hydroquinone & 4.25 & 2.29 & 0.29 & 26.56 \\
Salicylic acid & 4.32 & 2.11 & 0.39 & 27.00 \\
Control & 2.96 & 1.02 & 0.18 & 18.50 \\
LSD at 0.05 & 0.30 & 0.14 & 0.05 & 1.86 \\
\hline
\end{tabular}

Biochemical changes in cowpea plants treated with the tested IRCs:

The activity of peroxidase (PO), polyphenol oxidase (PPO), phenylalanine ammonia-lyase (PAL) and pathogenesis-related (PR) protein (chitinase and $\beta-1,3-$ glucanase) and phenolic compounds in plants treated with the inducers chemical resistance inoculated with the pathogenic fungus were assessed.

Peroxidase activity:

Data in Fig. (3) show that PO activity in cowpea plants treated with the tested inducer resistance chemicals (KS, PG, HQ and SA) and inoculated with $M$. phaseolina was higher in the tested inducer resistance chemicals than in untreated plants either inoculated with the pathogenic fungus or non-inoculated (control), ten days after the application. Cowpea plants treated with PG recorded the highest levels of PO activity followed by HQ, while plants treated with KS recorded the lowest increase , 10 days after the of application. Inoculated untreated plants recorded high PO activity more than non-inoculated untreated plants (control). The highest levels of PO was noticed 8 days after treatment in all cases then decreased progressively. 


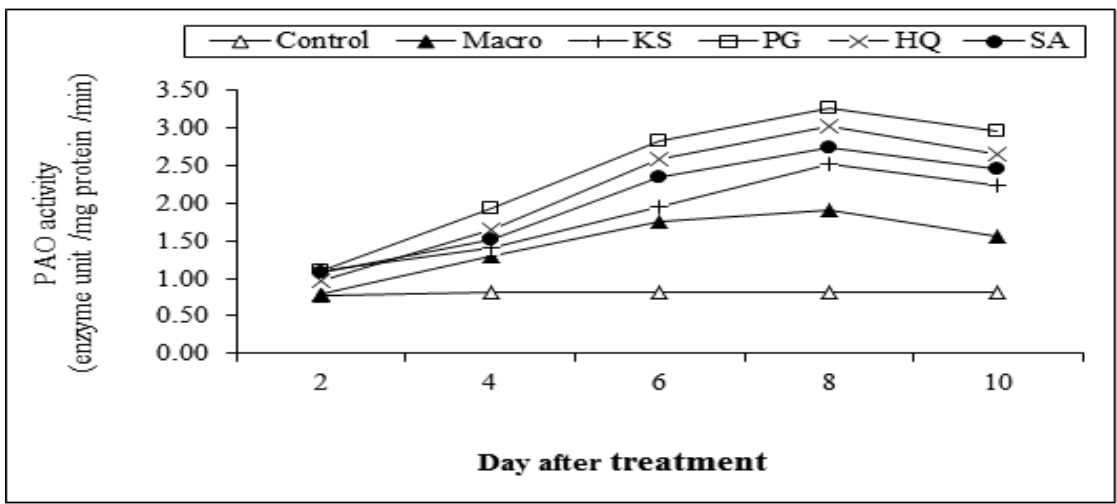

Figure (3): Activity of peroxidase (PO) in cowpea plants treated with the tested IRCs and inoculated with $M$. phaseolina using untreated plants either inoculated with the tested fungus or non-inoculated plant (control).

Polyphenoloxidase (PPO) activity:

Data illustrated in Fig. (4) show that all the tested IRCs increased the level of PPO activity in cowpea plants inoculated with M. phaseolina, ten days after the application compared with untreated plants either inoculated with the pathogenic fungus or non-inoculated plants (control). The maximum increase was recorded by all treatments eight days after treatment then decreased. PG treatment recorded the highest level followed by SA during all the detection periods, while KS and HQ, gave the lowest activity. On the other hand, in all cases, untreated cowpea plants and inoculated with the pathogenic fungus recorded high levels of PPO activity more than uninoculated untreated (control).

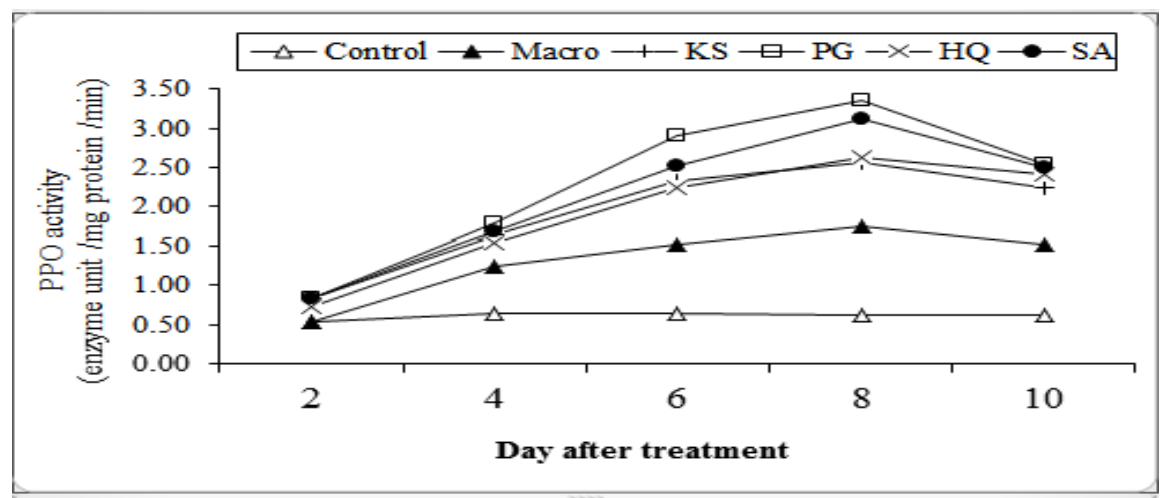

Figure (4): The activity of polyphenoloxidase (PPO) in cowpea plants treated with the tested IRCs and inoculated with M. phaseolina using untreated plants either inoculated with the tested fungus or non-inoculated plants (control).

Egypt. J. Phytopathol., Vol. 47, No. 1 (2019) 
Phenylalanine ammonia-lyase activity:

Data illustrated in Fig. (5) reveal that the levels of PAL activity in treated inoculated plants with the tested IRCs were increased than non-inoculated untreated plants (control), ten days after the application. The highest increase of the PAL activity was achieved by all tested IRCs, six days after application then decreased gradually. On the other hand, the highest increase in PAL activity was occurred in inoculated plants and treated with PG followed by SA compared with the other two treatments. Also, untreated plants and inoculated with the pathogenic fungus recorded high PAL level more than non-inoculated untreated (control), ten days after the application.

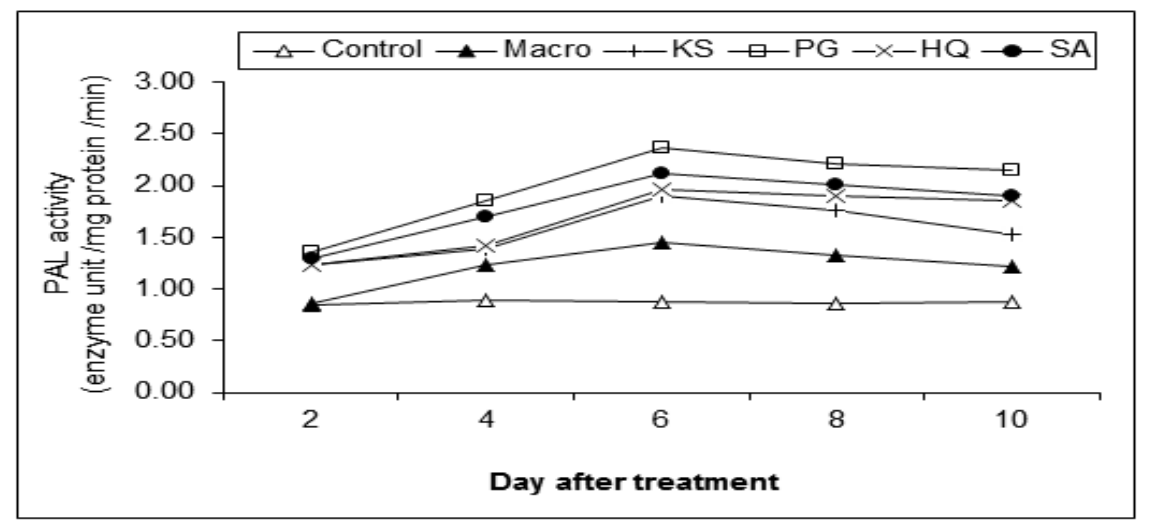

Figure (5): Activity of phenylalanine ammonia-lyase (PAL) in cowpea plants treated with the tested IRCs and inoculated with M. phaseolina using untreated plants either inoculated with the tested fungus or noninoculated plant (control).

Pathogenesis related $(P R)$ proteins:

The activity of the pathogenesis-related (PR) proteins (chitinase and $\beta-1,3-$ glucanase) in cowpea plants treated with the tested IRCs and inoculated with $M$. phaseolina were estimated. Data presented in Figs. $(6 \& 7)$ show that all the tested inducer resistance chemicals increased the activity of chitinase and $\beta-1,3$-glucanase enzymes in cowpea plants inoculated with the tested fungus compared with untreated plants either inoculated with the pathogenic fungus or non-inoculated (control), ten days after the application. Cowpea plants treated with PG and SA treatments recorded more activity of both enzymes than hydroquinone and potassium silicate treatments. However, the highest activity of both enzymes was shown 8 days after the application of the tested inducer resistance chemicals then decreased gradually. Also, the activity of both enzymes recorded high levels in cowpea plants inoculated with the pathogenic fungus more than non-inoculated untreated (control). 


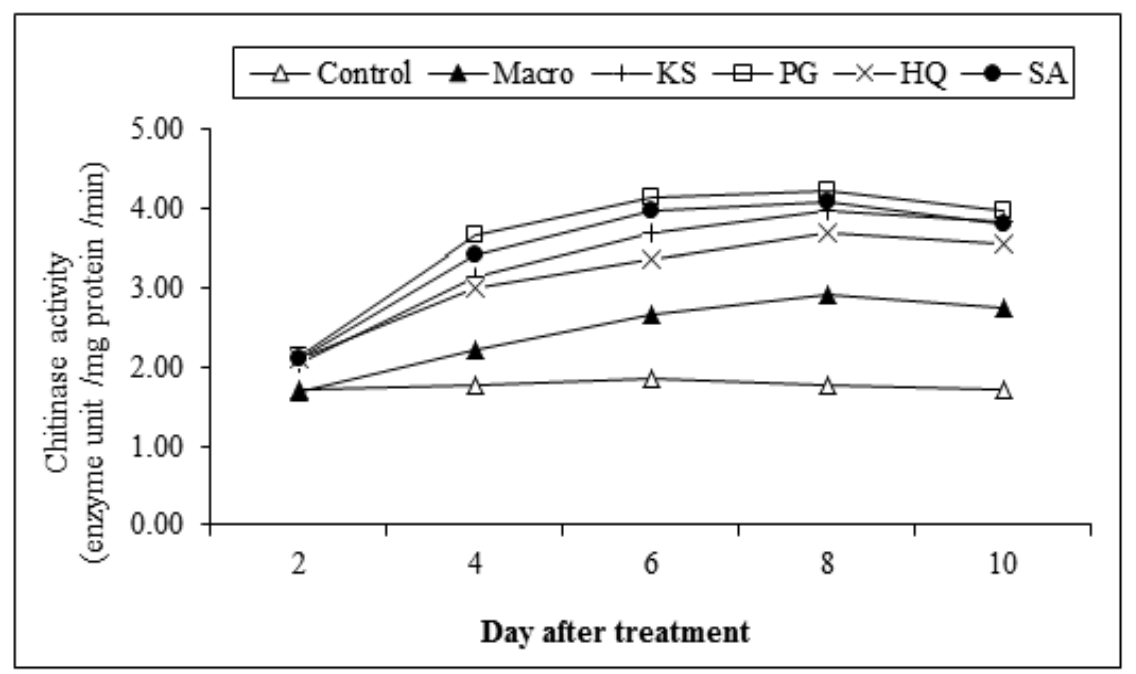

Figure (6): Activity of chitinase in cowpea plants treated with the tested IRCs and inoculated with $M$. phaseolina using untreated plants either inoculated with the tested fungus or non-inoculated plant (control).

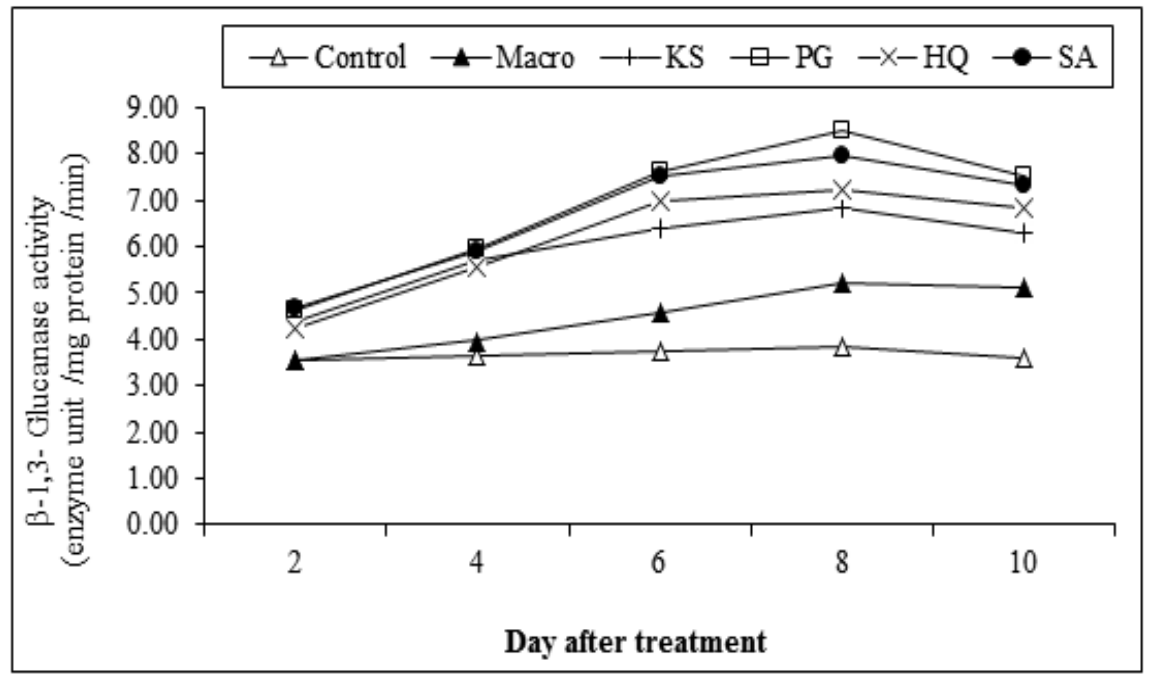

Figure (7): Activity of $\beta-1,3$ - glucanase in cowpea plants treated with the tested IRCs inoculated with $M$. phaseolina using untreated plants either inoculated with the tested fungus or non-inoculated plant (control).

Egypt. J. Phytopathol., Vol. 47, No. 1 (2019) 


\section{Total phenol content:}

Data presented in Fig. (8) reveal that all the tested inducer resistance chemicals increased the accumulation of total phenol compounds in cowpea plants inoculated with $M$. phaseolina more than untreated cowpea plants either inoculated with the tested pathogen or non-inoculated (control). Also, untreated cowpea plants inoculated with the pathogenic fungus recorded high content of total phenol compounds compared with non-inoculated (control). PG followed by SA recorded the highest contents of total phenol compounds more than HQ and KS, ten days after the application. Moreover, the maximum level of phenolic compounds was recorded, six days after the application then decreased gradually.

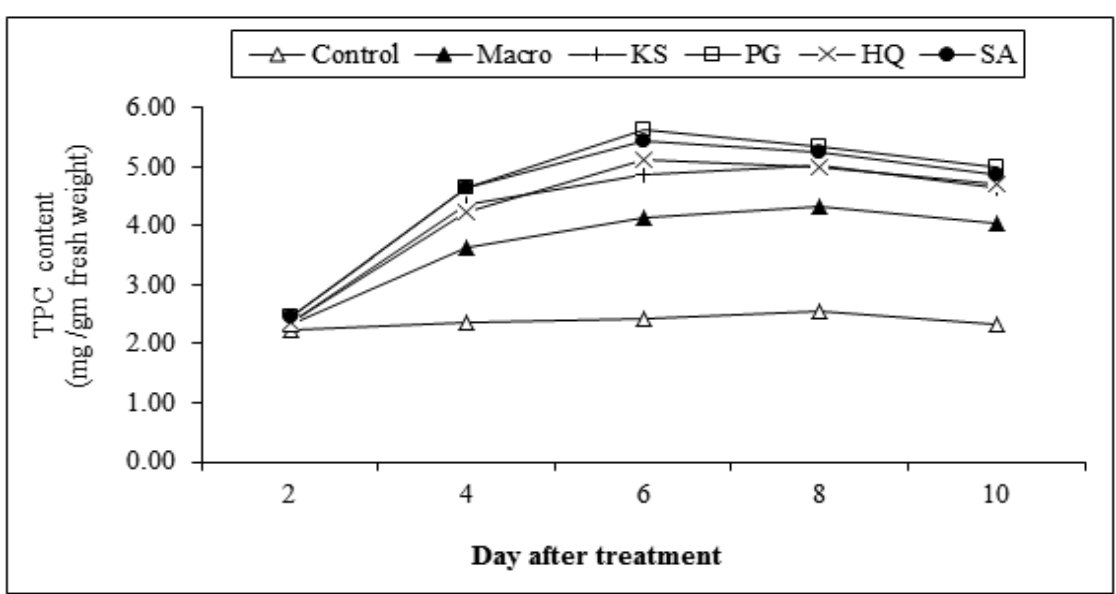

Figure (8): Total phenols content in cowpea plants treated with the tested IRCs and inoculated with $M$. phaseolina using untreated plants either inoculated with the tested fungus or non-inoculated(control).

\section{Discussion}

Cowpea (Vigna unguiculata (L.) Walp.) is one of the most famous members of family Fabaceae worldwide. It is of major importance to the livelihoods of millions of relatively poor people in less developed countries of the tropics (Singh et al., 1997).It is an important grain legume widely consumed in Egypt as a cheap source of high-quality protein and other important nutrients (Da Silva et al., 2018) Great losses occur as a result of seed decay and seedling damping-off caused by some pathogens including M. phaseolina (El-Mohamedy et al., 2006). The fungus is a soil- and seed-borne plant pathogen with a very wide host range that attacks more than 500 crop species including some of the most important crops such as soybean, cotton, and corn (Gupta et al., 2012). The wide host range and the primary inoculum source of the pathogen (microsclerotia) which can survive up to 15 years depending on environmental conditions complicate management schemas (Cook et al., 1973; 
Papavizas, 1977; Short et al., 1980). Microsclerotia in soil, infected seeds or host tissues serve as primary inoculum (Abawi and Pastor-Corrales, 1990). Root exudates induce germination of microsclerotia and root infection of hosts. The infective hyphae enter into the plant through root epidermal cells or wounds. During the initial stages of pathogenesis, the mycelium penetrates the root epidermis and is restricted primarily to the intercellular spaces of the cortex of the primary roots. As a result, adjacent cells collapse and heavily infected plantlets may die. At flower onset, the fungal hyphae grow intracellularly through the xylem and form microsclerotia that plug the vessels (Mayek-Pérez et al., 2002) and disrupt host cells. The infected plants show necrotic lesions on stems, branches, and peduncles.

The use of fungicides to control the charcoal disease of economically important crops has been proved in agriculture for many years. However, a growing concern is increased for human safety and public perception that pesticides are harmful to human health and the environment (Gullino \& Kuijpers, 1994; Carvalho, 2017). So, recent research priorities preferred disease control programs that are safe and compatible with sustainable agriculture.

Isolation trials from rotted roots of cowpea roots showing charcoal-rot symptoms yielded 16 isolates of $M$. phaseolina conforming to other reports (El-Mohamedy et al., 2006 \& Amusa et al., 2007). Pathogenicity test demonstrated that all the obtained isolates were able to infect cowpea plants caused typical charcoal rot symptoms with different percentages of disease severity.

The results indicated that all the tested IRCs, i.e. potassium silicate (KS), hydroquinone (HQ), propyl gallate (PG) and salicylic acid (SA) were able to decrease charcoal rot caused by $M$. phaseolina either in pots or under field conditions. Propyl gallate recorded the highest protection against charcoal rot severity followed by Hydroquinone, while K- silicate and salicylic acid gave the lowest protection. On the other hand, all the tested IRCs increased the tested growth parameters (plant height, number of branches, fresh and dry weight) and yield components (pod length, number of seeds/pods, the weight of 100 seeds and total seed yield Kg /feddan) during summer season 2017 under field conditions. Induced resistance was reported to be activated by exogenous application of KS, PG, HQ and SA (Mostafa, 2006; Abdel-Monaim and Ismail, 2010; Al-Askar et al., 2013; Thakur \& Sohal, 2013; Abdel-Monaim et al., 2015 ; Ezzat et al., 2015; and Wang et al., 2017).

Abdel-Monaim and Ismail (2010) reported that propyl gallate at $200 \mathrm{ppm}$ was more efficient in reducing infection with damping-off, root rot and wilt diseases in pepper plants as well as increasing the seedling fresh weight, dry weight, plant height, plant branching, number of pod/ plant and pod yield/ plant. Also, tuber treatment by Arbuscular mycorrhiza fungi+ HQ was the most effective in increasing the survival of Jerusalem Artichoke seedlings infected by Sclerotinia sclerotiorum

Egypt. J. Phytopathol., Vol. 47, No. 1 (2019) 
or Rhizoctonia solani as compared to the infected controls without treatment and was the most effective treatment in reducing disease incidence of tuber rots and plant mortality (Ezzat et al., 2015). Also, the treatment with HQ recorded positive effect on disease parameters caused by $S$. sclerotiorum and $R$. solani (Al-Askar et al., 2013). Additionally, Elwakil (2003) found that HQ improved the growth of peanut and raised the yield by up to $50 \%$. However, HQ as an antioxidant is a molecule capable of inhibiting the oxidation of other molecules, which delay or inhibit oxidative damage to target molecules such as lipids, proteins, nucleic acids and carbohydrates (Anbudhasan et al., 2014).

The mode of action of Si-induced resistance is acting as a physical barrier and as a modulator of host resistance to pathogens. Silicon deposited beneath the cuticle and forms a cuticle-Si double layer to protect the plant from pathogen penetration, therefore decreasing disease incidence (Ma and Yamaji, 2006\& 2008). Siliconinduced resistance is associated with the density of silicified epidermal cells, the double cuticular layer, the intensified Si-cellulose membrane, and complexes formed with organic compounds in cell walls that support plants mechanically. The physical barriers decrease pathogen penetration and plant cells become resistant to enzymatic degradation by the fungal pathogen during invasion (Inanaga et al., 1995; Fauteux et al., 2005; Datnoff et al., 2007; Van et al., 2013).

Treatment with SA and its derivative induced expression of pathogenesis-related (PR) proteins (Malamy et al., 1990 and Gaffney et al., 1993). Salicylic acid plays an important role in the induction of plant defense against several plant pathogens (Kumar, 2014). Also, it may affect different biochemical processes in plants, including seed germination, ion uptake, and permeability of membrane (Dolatabadian et al., 2009). It regulates the activities of various enzymes such as, peroxidase (POD), polyphenoloxidase PPO, phenylalanine ammonia-lyase (PAL) which are the major components of induced plant defense against biotic and abiotic stresses (Idrees et al., 2011).

It has been found that, all the tested IRCs increased cowpea contents of nitrogen $(\mathrm{N})$, potassium $(\mathrm{K})$, phosphorus $(\mathrm{P})$, and crude protein compared with control. SA recorded the highest levels of all tested mineral contents and crude protein, while KS treatment recorded the lowest cowpea plant contents from all tested minerals during the growing season at two locations. In this respect, many investigations reported the use of some chemical inducers to increase plant resistance, growth parameters and mineral contents in several crops (Chandra et al., 2007; Maity and Bera, 2009; Khan et al., 2010 and Ezzat et al., 2015). The tested IRCs may encourage some defense mechanisms i.e. oxidative enzymes, and phenolic compounds (AbdelMonaim et al., 2015). In this study, all tested IRCs increased activity of defenserelated enzymes, including peroxidase, polyphenoloxidase, phenylalanine ammonialyase, pathogenesis-related (PR) protein (chitinase and $\beta-1,3$ - glucanase) in cowpea plants inoculated with $M$. phaseolina compared with control plants during the 
experimental period. In general, the activity of these enzymes begin to accumulation two days of treatment and reached maximum levels at 6 days for PAL and 8 days for PO, PPO, chitinase and $\beta-1,3-$ glucanase, respectively, then the activities of these enzymes were decreased progressively. In this respect, defense enzymes such as peroxidase, polyphenoloxidase, phenylalanine ammonia-lyase, chitinase, and $\beta$ 1,3 glucanase are related to induced resistance inducement in plants (Gajanayaka $\mathrm{et}$ al., 2014; Seneviratne et al., 2014; Prasannath and De Costa, 2015). Peroxidases are a class of PR proteins that belong to PR-9 and induced in host plant by pathogen infection. They are expressed to limit the cellular extending of infection by the establishment of structural barriers or producing reactive oxygen species (Passardi et $a l .$, 2005). Moreover, peroxidases have been implicated in a range of defense-related processes, including the hypersensitive response, lignification, cross-linking of phenolics and glycoproteins, suberization and phytoalexin production (Nicholson \& Hammerschmidt, 1992; Wojtaszek, 1997). However, polyphenol oxidases or tyrosinases (PPOs) are a group of copper-containing enzymes that catalyze the oxidation of hydroxy phenols to their quinone derivatives, which have antimicrobial activity (Chunhua et al., 2001). Quinones are effective inhibitors of SH (Sulfhydryl enzymes) group of enzymes which may inhibit the pathogens (Goodman et al., 1967). A significant increase in PPO activity in response to host-pathogen interactions has been found in several plant species. Also, several studies reported a positive correlation between PPO expression and resistance/tolerance to biotic stresses (Taranto et al., 2017). Meantime, Phenylalanine ammonia-lyase (PAL) catalyzes the non-oxidative deamination of phenylalanine into trans-cinnamic acid and ammonia which is the initial step in the biosynthesis of phenolic compounds. PAL which can be induced by some biotic and abiotic stresses is one of the important enzymes in plants due to the synthesis of various phenolic compounds as well as anthocyanin that are responsible for the resistance of plant pathogens (Dixon and Paiva, 1995). Other defense enzymes include pathogenesis-related proteins (PRs) such as $\beta-1,3$-glucanases PR-2 and chitinases PR-3, which are responsible for the hydrolysis of cell wall components in sequence such as chitin and $\beta-1,3-$ glucans (Ebrahim et al., 2011). $\beta$-glucanases participate in the decomposition of glucans like callose which occurs in plant tissues as one of the components of wall modifications involved in resistance responses (Smart, 1991). While, chitinases improves plant defense against chitin containing plant pathogens (Jalilet al., 2015). B-1, 3-glucan and chitin, a polymer of $\mathrm{N}$-acetylglucosamine are major cell wall components of many fungi. Since $\beta-1,3$ glucanase and chitinases are capable of attacking the cell wall of fungal pathogens, these enzymes have been proposed as direct defense enzymes of plants (Abeles et al., 1970). Also, Mauch et al., (1988) reported that in combination, chitinase and $\beta-1,3$ glucanaseact synergistically to inhibit fungal growth. The mode of action of chitinase is relatively simple. They decompose the cell wall chitin polymers in situ, resulting in a weakened cell wall and showing fungal cells osmotically sensitive (Jach et al., 1995).

Egypt. J. Phytopathol., Vol. 47, No. 1 (2019) 
The obtained data revealed that total phenols were increased in cowpea treated plants and inoculated with $M$. phaseolina. The highest accumulation of phenols was recorded at 6 days from application. These results suggested that these chemicals may play an important role in controlling the cowpea charcoal rot, though they have induction of systemic resistance in cowpea plants. In this regard, the role of phenolic compounds in disease resistance was postulated by Nicholson and Hammerschmidt (1992). The phenolic compounds may contribute to enhance the mechanical strength of the host cell wall and may also inhibit the fungal growth, as phenolics are fungi toxic in nature. Altering the level of phenolic compounds in plants has been demonstrated to change disease susceptibility (Yao et al., 1996).

\section{Ref e r e n e s}

Abawi, G.S. and Pastor-Corrales, M.A. 1990. Seed transmission and effect of fungicide seed treatments against Macrophomina phaseolina in dry edible beans. Turrialba, 40: 304-339.

Abdel-Aziz, T.K.; Hamed, N.M. and Aboel-Goud, S.H.A. 2008. Response of cowpea to application of $\mathrm{K}$ and farmyard manure under New Valley conditions. J. Agric. Sci., Mansoura Univ., 33 (3):1675-1690.

Abdel-Monaim, M.F. and Ismail, M.E. 2010.The use of antioxidants to control rootrot and wilt diseases of pepper. Not. Sci. Biol., 2 (2): 46-55.

Abdel-Monaim, M.F.; Atwa, M.A.M. and Morsy, K.M. 2015. Induce systemic resistance against root-rot and wilt diseases in fodder beet Beta vulgaris L. var. rapacea Koch.) by using potassium salts. J. Plant Pathol. Microbiol., 6 (10): $1-8$.

Abeles, F.B.; Bosshart, P.; Forrence, L.E. and Habiz, W. 1970. Preparation and purification of glucanase and chitinase from bean leaves. Plant Physiol., 47(1): 129-134.

Adandonon, A. 2004. Damping-off and Stem-rot of Cowpea in Benin Caused by Sclerotium rolfsii. Ph.D. Thesis, Fac. of Nat. and Agric. Sci., Univ. of Pretoria, Benin.

Adegbite, A.A. and Amusa, N.A. 2010. The major economic field diseases of cowpea in the humid agro-ecologies of south-western Nigeria. Arch. of Phytopathol. and Plant Protec., 43:1608-1618.

Anbudhasan, P.; Surendraraj, A.; Karkuzhali, S. and Sathishkumaran, P. 2014. Natural antioxidants and its benefits. Inter. J. of Food and Nut. Sci..; 3(6): 225232.

Afouda, L.C.A.; Schulz, D.; Wolf, G. and Wydra, K. 2012. Biological control of Macrophomina phaseolina on cowpea (Vigna unguiculata) under dry conditions by bacterial antagonists. Inter. J. Biol. Chem. Sci., 6: 5068-5077 
Al-Askar, A.A.; Ghoneem, K.M. and Rashad, Y.M. 2013. Management of some seed-borne pathogens attacking alfalfa plants in Saudi Arabia. Afr. J. Microbiol. Res., 7: 1197-1206.

Al-Askar, A.A.; Ghoneem, K.M.; Ezzat, A.E.S. and Saber, W.I.A. 2014. Improving growth and productivity as well as controlling Sclerotium rolfsii in Jerusalem artichoke using biotic and abiotic agents. J. Pure Appl. Microbiol., 8: 279-291.

Amusa N.A.; Okechukwu, R.U. and Akinfenwa B. 2007. Reactions of cowpea to infection by Macrophomina phaseolina isolates from leguminous plants in Nigeria. Afr. J. of Agric. Res., 2(3):73-75.

Biles, C.L. and Martyn, R.D. 1993. Peroxidase, polyphenoloxidase and shikimatede hydrognase isozymes in relation to tissue type, maturity and pathogen induction of watermelon seedling. Plant Physiol. Biochem., 31: 499-506.

Bliss, F.A. 1975. Cowpeas in Nigeria. 151-158, In: Milner, M., eds. Proc. of a Symp. on Nut. Improv. of Food Leg. by Dreed., New York, USA.

Carvalho, F.P. 2017. Pesticides, environment, and food safety. Food Ener. Sec., 60: 48-60. doi: 10.1002/fes3.108

Cavalcanti, F.R.; Resende, M.L.; Carvalho, C.P.; Silveira J.A. and Oliveira, J.T. 2007. An aqueous suspension of Crinipellis perniciosa mycelium activates tomato defense responses against Xanthomonas vesicatoria. Crop Protec., 6:72938.

Chandra, A.; Anand, A. and Dubey, A. 2007. Effect of salicylic acid on morphological and biochemical attributes in cowpea. J. Environ Biol., 28(2):193196.

Chakraborty, M.R. and Chatterjee, N.C. 2007. Interaction of Trichoderma harzianum with Fusarium solani during its pathogenesis and the associated resistance of the host. Asian J. Exp. Sci., 21: 351-355.

Che'rif, M.; Asselin, A. and Be'langer, R.R. 1994. Defense responses induced by soluble silicon in cucumber roots infected by Pythium spp. Phytopathology, 84: 236-242.

Chunhua, S.; Ya, D.; Bingle, X.; Xiao, L.; Yonshu, X. and Qinguang, L. 2001. The purification and spectral properties of PPO I from Nicotiana ntababcum. Plant Molec. Biol., 19: 301-314.

Cook, G.E.; Boosalis, M.G.; Dunkle, L.D. and Odvody, G.N. 1973. Survival of Macrophomina phaseoli in corn and sorghum stalk residue. Plant Dis. Rep., 57: 873-875.

Cottenie, A.; Verloo, M.; Kiekns, L.; Velghe, G. and Camerlynek, R. 1982. Chemical Analysis of Plants and Soils. Lab. of Analyt. and Agrochem., State Univ., Ghent Belgium. 63 pp.

Egypt. J. Phytopathol., Vol. 47, No. 1 (2019) 
Da Silva, A.C; Santos, D.C; Teixeira, D.L.J..; Da Silva, P.B.; Santos, R.C.D and Amauri, S. 2018. Cowpea: A Strategic Legume Species for Food Security and Health. In: Legume Seed Nutra. Res. (Jimenez-Lopez, J.C. and Clemente, A. eds.), Intec. Open. pp 47-65. http://dx.doi.org/10.5772/ intechopen.79006

Datnoff, L.E.; Elmer, W.H. and Huber, D.M. 2007. Mineral Nutrition and Plant Disease. St. Paul, MN: The Amer. Phytopathol. Soc., 233-246.

Demooy, E.; Yosafi, E. and Chapman, P.L. 1989. A Screening Method for Identification of Sources of Resistance to Macrophomina phaseolina in the Seedling Stage of Cowpea (Vigna unguiculata Walp). Tech. Report TR89-9. Colorado State Univ.

Dhingra, O.D. and Sinclair, J.B. 1977. An annotated bibliography of Macrophomina phaseolina, 1905-1975. Published cooperatively by Universidade Federal de Viscosa, Viscosa, Minas Gerais, Brazil, and Univ. of Illinois, UrbanaChampaign, IL, USA. pp. 277.

Dhingra, O.D. and Sinclair, J.B. 1985. Basic Plant Pathology Methods. CRC, Boca Raton, Florida, USA.

Dixon, R.A. and Paiva, N.L. 1995. Stress-induced phenylpropanoid metabolism. Plant Cell, 7:1085-1097.

Dolatabadian, A.; Modarres Sanavy, S.A.M and Sharifi, M. 2009. Effect of salicylic acid and salt on wheat seed germination. Acta Agric. Scandi. Sec. B -Soil and Plant Sci., 59(5): 456-464.

Ebrahim, S.; Usha, K. and Singh, B. 2011. Pathogenesis related (PR) proteins in plant defense mechanism. In: Science against microbial pathogens: communicating current research and technological advances (Mendez-Vilas, A. ed.). pp. 1043-1054.

EL-Mohamedy, R.S.R.; Abdalla, M.A. and Badiaa, R.I. 2006. Soil amendment and bio- priming treatments as alternative fungicides for controlling root-rot diseases on cowpea plants in Nobria province. Res. J. Agric. and Biol. Sci., 2:391-398.

Elwakil, M.A. 2003. Use of antioxidant hydroquinone in the control of seed-borne fungi of peanut with special reference to the production of good quality seed. Pakis. J. Plant Pathol., 2(2): 75-79.

Ezzat, A.S.; Ghoneem, K.M.; Saber, W.I.A. and Al-Askar, A.A. 2015. Control of wilt, stalk and tuber rots diseases using arbuscular mycorrhizal fungi, Trichoderma species and hydroquinone enhances yield quality and storability of Jerusalem artichoke (Helianthus tuberosus L.). Egypt. J. of Biol. Pest Cont., 25 (1): 11-22.

Fauteux, F.; Remus-Borel, W.; Menzies, J. G. and Belanger, R. R. 2005. Silicon and plant disease resistance against pathogenic fungi. FEMS Microbiol. Lett., 249: 16. 
French-Monar, R.D.; Rodrigues, F.A.; Korndörfer, G.H. and Datnoff, L.E. 2010. Silicon suppresses Phytophthora blight development on bell pepper. $J$. Phytopathol., 158: 554-560.

Gaffney, T.; Friedrich, L.; Vernooij, B.; Negrotto, D.; Nye, G.; Uknes, S.; Ward, E.; Kessmann, H. and Ryals, J. 1993. Requirement of salicylic acid for the induction of systemic acquired resistance. Science, 261: 754-756.

Gajanayaka, G.M.D.R.; Prasannath, K. and De Costa, D.M. 2014. Variation of chitinase and $3-1,3$ glucanase activities in tomato and chili tissues grown under different crop management practices and agroecological regions. Proc. Peradeniya Univ. Inter. Res. Sess. (PURSE 2014),Vol. 18, July 4 \& 5, Univ. of Peradeniya, Sri lanka, pp. 519.

Gauillard, F.; Richard-Forget, F. and Nicolas, J. 1993. New spectrophotometric assay for polyphenol oxidase activity. Annu. Biochem., 215:59-65.

Goodman, R.N.; Kiraly, Z. and Zaitlin, M. 1967. The Biochemistry and Physiology of Infectious Plant Diseases. Van Nostrand Co. Inc., Princeton, New Jersey, 354 $\mathrm{p}$

Guérin, V.; Lebreton, A.; Cogliati, E.E.; Hartley, S.E.; Belzile, F.; Menzies, J.G. and Belanger, R.R. 2014. A zoospore inoculation method with Phytophthora sojae to assess the prophylactic role of silicon on soybean cultivars. Plant Dis., 98: 16321638.

Gullino, M.L. and Kuijpers, L.A.M. 1994. Social and political implications of managing plant diseases with restricted fungicides in Europe. Ann. Rev. Phytopathol., 32: 559-579.

Gupta, G.K.; Sharma, S.K. and Ramteke, R. 2012. Biology, epidemiology and management of the pathogenic fungus Macrophomina phaseolina (Tassi) Goid with special reference to charcoal-rot of soybean (Glycine max (L.) Merrill). J. of Phytopathol., 160:167-180.

Heine, G.; Tikum, G. and Horst, W. J. 2007. The effect of silicon on the infection by and spread of Pythium aphanidermatum in single roots of tomato and bitter gourd. J. Exp. Bot., 58:569-577.

Huang, C.H.; Roberts, P.D. and Datnoff, L.E. 2011. Silicon suppresses Fusarium crown and root rot of tomato. J. Phytopathol., 159: 546-554.

Idrees, M.; Naeem,M.; Aftab, T.; Khan, M.M.A. and Moinuddin, A.S. 2011. Salicylic acid mitigates salinity stress by improving antioxidant defense system and enhances vincristine and vinblastine alkaloids production in periwinkle [Catharan thusroseus (L.) G. Don]. Acta. Physiol. Plant, 33:987-999.

Inanaga, S.; Okasaka, A. and Tanaka, S. 1995. Does silicon exist in association with organic compounds in rice plant?. J. Soil Sci. Plant Nut., 11:111-117.

Egypt. J. Phytopathol., Vol. 47, No. 1 (2019) 
Jach, G.; Gornhardt, B.; Mundy, J.; Logemann, J.; Pinsdorf, E.; Leah, R.; Schell, J. and Maas, C. 1995. Enhanced quantitative resistance against fungal disease by combinatorial expression of different barley antifungal proteins in transgenic tobacco. Plant J. 8: 97-109.

Jalil, S.U.; Mishra, M. and Ansari, M.I. 2015. Current view on chitinase for plant defence. Trend. in Bio. Sci.., 8(24): 6733-6743.

Karthikeyan, V.; Brindha, S.; Annadurai, B. and Gangwar, S. K. 2015. Biological control of Macrophomina phaseolina (Tassi) Goid root-rot in Vigna mungo (Black gram) with Trichoderma spp. Inter. J. Ad. Biol. Res., 5(2): 118-127

Kessmann, H.; Staub, T.; Hofmann, C.; Maetzke, T.; Herzog, J.; Ward, E.; Uknes, S. and Ryals, J. 1994. Induction of systemic acquired resistance in plants by chemicals. Annu. Rev. of Phytopathol., 32: 439-459.

Khalili, E.; Javed, M.A.; Huyop, F.; Rayatpanah, S.; Jamshidi, S. and Wahab, R.A. 2016. Evaluation of Trichoderma isolates as potential biological control agent against soybean charcoal-rot disease caused by Macrophomina phaseolina. Biotechnol. and Biotechnol. Equip., 30: 479-488.

Khan, N.A.; Syeed, S.; Masood, A.; Nazar, R. and Iqbal, N. 2010. Application of salicylic acid increases contents of nutrients and antioxidative metabolism in mung bean and alleviates adverse effects of salinity stress. Inter. J. Plant Biol., 1:1-8.

Kuck, K.H. and Gisi, U. 2007. FRAC Mode of Action Classification and Resistance Risk of Fungicides. In: Modern Crop Protec. Comp. (Krämer, W. and Schirmer, U. eds.), Wiley-VCH Verlag GmbH \& Co. KGaA, Weinheim, Germany, pp. 415-432.

Kumar, D. 2014. Salicylic acid signaling in disease resistance. Plant Sci., 228: 127124.

Kyei-Boahen, S.; Savala, C.E.N.; Chikoye, D. and Abaidoo, R. 2017. Growth and yield responses of cowpea to inoculation and phosphorus fertilization in different environments. Front. Plant Sci., 8: article 646.

Ma, J.F. and Yamaji, N. 2006. Silicon uptake and accumulation in higher plants. Trends in Plant Sci., 11: 392-397.

Ma, J. F. and Yamaji, N. 2008. Functions and transport of silicon in plants. Cell and Molec. Life Sci., 65: 3049-3057.

Maity, U. and Bera, A. K. 2009. Effect of exogenous application of brassinolide and salicylic acid on certain physiological and biochemical aspects of green gram [Vignaradiata (L.) Wilczek].Ind. J. of Agric. Res., 43(3):194-199. 
Malamy, J.; Carr, J.P.; Klessig, D.F. and Raskin, I. 1990. Salicylic acid: a likely endogenous signal in the resistance response of tobacco to viral infection. Science, 250: 1002-1004

Mauch, F.; Mauch-Mani, B. and Boller, T. 1988. Antifungal hydrolases in pea tissue: II. Inhibition of fungal growth by combinations of chitinase and $\beta-1,3-$ glucanase. Plant Physiol., 88: 936-942.

Mayek-Pérez, N.; Garcia-Espinosa, R.; López-Castañeda, C.; Acosta-Gallegos, J. A. and Simpson, J. (2002). Water relations, histopathology, and growth of common bean (Phaseolus vulgaris L.) during pathogenesis of Macrophomina phaseolinaunder drought stress. Physiol. Plant Pathol.. 60: 185-195

Mengistu, A.; Ray, J.D.; Smith, J.R. and Paris, R.L. 2007. Charcoal-rot disease assessment of soybean genotypes using a colony-forming unit index. Crop Sci., 47:2453-2461.

Mohanapriya, R.; Naveenkumar, R. and Balabaskar, P. 2017. Survey, virulence and pathogenicity of root-rot incidence of cowpea in selected districts of tamilnadu caused by Macrophomina phaseolina (Tassi.) Goid. Inter. J. Curr. Microbiol. App. Sci., 6(3): 694-705.

Mostafa, W.E.B. 2006. Studies on Some Cumin Diseases. M.Sc. Thesis, Fac. Agric., Minia Univ. Pp.165Pp

Muthomi, J.W.; Oteino, P.E.; Chemining, W.A .G.N.; Nderitu, J.H. and Wagacha, J.M. 2007. Effect of legume root-rot pathogens and fungicide seed treatment on nodulation and biomass accumulation. J. of Biol. Sci., 7 (7): 1163-1170.

Ndiaye, M. 2007. Ecology and Management of Charcoal-Rot (Macrophomina phaseolina) on Cowpea in the Sahel. Ph.D. Thesis Wageningen Univ. and Res. Centre, Wageningen, The Netherlands. 107 pp.

Nicholson, R.L. and Hammerschmidt, R. 1992. Phenolic compounds and their role in disease resistance. Ann. Rev. of Phytopathol.., 30: 369-389.

Page, A.L.; Miler, R.H. and Keeney, D.R. 1982. "Methods of Soil Analysis", part 2. Chemical and microbiological properties. Agron. Monog., 9(2): 539-624.

Pan, S.Q.; Ye, X.S.and Kuc, J. 1991. A technique for detection of chitinase, beta1,3-glucanase, and protein-patterns after a single separation using polyacrylamide-gel electrophoresis or isoelectrofocusing. Phytopathology, 81: 970-974 .

Papavizas, G.C. 1977. Some factors affecting survival of sclerotia of Macrophomina phaseolina in soil. Soil Biol. Biochem., 9: 337-341.

Passardi, F.; Cosio, C.; Penel, C. and Dunand, C. 2005. Peroxidases have more functions than a Swiss army knife. Plant Cell Rep., 24(5): 255-265.

Egypt. J. Phytopathol., Vol. 47, No. 1 (2019) 
Pearson, C.A.S.; Schwenk, F.W.; Crowe, F.J. and Kelley, K. 1984. Colonization of soybean roots by Macrophomina phaseolina. Plant Dis., 68:1086-1088.

Phillips A.J.L.; Alves, A.; Abdollahzadeh, J.; Slippers, B.; Wingfield, M.J.; Groenewald, J.Z. and Crous, P.W. 2013. The Botryosphaeriaceae: genera and species known from culture. Studies in Mycology, 76: 51-167.

Prasannath, K. and De Costa, D.M. 2015. Induction of peroxidase activity in tomato leaf tissues treated with two crop management systems across a temperature gradient. Proc. of the Inter. Conf. on Dry Zone Agric. (ICDA). Fac. of Agric., Univ. of Jaffna, Sri Lanka.

Reuveni, R.; Nachmias, A. and Kikun, J. 1983. The Role of seed-borne inoculum on the development of Macrophomina phaseolina on melon. Plant Dis., 67: 280281.

Saikia, R.; Yadav, M.; Varghese, S.; Singh, B.P.; Gogoi, D.K.; Kuma, R. and Arora K.D. 2006. Role of riboflavin in induced resistance against Fusarium wilt and charcoal-rot diseases of chickpea. Plant Pathol. J., 22 (4): 339-347.

Seneviratne, D.M.A.S.; Prasannath, K. and De Costa, D.M. 2014. Quantification of phenylalanine ammonia lyase activity in tomato and chili tissues grown under different crop management practices and agro-ecological regions in Sri Lanka. Proc. of the $1^{\text {st }}$ Fac. of Agric. Undergra. Res. Symp., $23^{\text {rd }}$ December. p. 3.

Short, G.E.; Wyllie, T.D. and Bristow, P.R. 1980. Survival of Macrophomina phaseolina in soil and residue of soybean. Phytopathology, 70: 13-17.

Silva, F. and Azevedo, C.A.V. 2009. Principal components analysis in the software Assistat-Statistical Attendance. In: World Congress on Computers in Agriculture, 7. Amer. Soc. of Agric. and Biol. Eng.

Singh, S.R. and Rachie, K.O. 1985. Cowpea Research, Production and Utilisation. Inter. Inst. of Trop. Agric. (IITA). John Wiley and Son, Chichester, Great Britain.

Singh, B.B.; Mohan, R.D.R.; Dashiell, K.E. and Jackai, L.E.N. 1997. Advances in Cowpea Research. Co-publication of Inter. Inst. of Trop. Agric. (IITA) and Japan Inter. Res. Cent, for Agric. Sci. (JIRCAS). IITA, Ibadan, Nigeria.

Smart, M.G. 1991. The Plant Cell Wall as a Barrier to Fungal Invasion. In: The Fungal Spore and Disease Initiation in Plants and Animals (Cole, G.C. and Hoch, H.C. eds.). Plenum Press, New York. pp. 47-66.

Smith, G.S. and Wyllie, T.D. 1999. Charcoal rot. In: Compendium of Soybean Disease (Hartman, G.L.; Sinclair, J.B. and Rupe, J.C. eds.) $4^{\text {th }}$ ed., St. Paul, MN, USA, Amer. Phytopathol., Soc., 29-31.

Sutton B. 1980. The coelomycetes: fungi imperfecti with pycnidia, acervuli and stromata. Kew, England: Common. W. Mycol. Inst. Assoc. Appl. Biol. 
Taranto, F.; Pasqualone, A. and Mangini, G. 2017. Polyphenol oxidases in crops: biochemical, physiological and genetic aspects. Inter. J. of Molec. Sc., 18: 377793.

Thakur, M. and Sohal, B.S. 2013. Role of elicitors in inducing resistance in plants against pathogen infection: A review. ISRN Biochem., Vol. 2013, Article ID 762412, 10 pages.

Van, B.J.; De Vleesschauwer, D. and Hofte M. 2013. Towards establishing broadspectrum disease resistance in plants: silicon leads the way. J. of Exp. Bot., 64: 1281-1293.

Wang, M.; Gao L.; Dong, S.; Sun, Y.; Shen, Q. and Guo, S. 2017. Role of Silicon on Plant-Pathogen Interactions. Front. Plant Sci. 8: Article 701. 14 pages.

Whan, J.A.; Dann, E.K. and Aitken, E.A. 2016. Effects of silicon treatment and inoculation with Fusarium oxysporum f. sp. vasinfectum on cellular defenses in root tissues of two cotton cultivars. Anпи. Bot., 118: 219-226.

Wirth, S.J. and Wolf, G.A. 1992. Micro-plate calorimetric assay for endo-acting cellulase, xylanase, chitinase, $\beta-1,3$-glucanase and amylase extracted from forest soil horizons. Soil Biol. Biochem., 24:511-519.

Wojtaszek, P. 1997. The oxidative burst: a plant's early response against infection. Biochem. J., 322: 681-692.

Xu, B.J. and Chang S.K.C. 2007. A Comparative study on phenolic profiles and antioxidant activities of legumes as affected by extraction solvents. J. of Food Sci., 72: 159-166.

Yao, C.; Zehnder, G.; Bauske, E. and Kloepper, J. 1996. Relationship between cucumber beetle (Coleoptera: Chrysomelidae) density and incidence of bacterial wilt of cucurbits. J. of Econ. Entomol. , 89: 510-514.

Zakir, M. 2018. Systemic acquired resistance (SAR) and it's application in crop plants improvement to biotic stresses: Review. Inter. J. of Res. Stud. in Sci. Eng. and Technol., 5: 17-24.

Corresponding author: Abdel-Monaim, M.F

E-mail: fowzy2008@yahoo.com

(Received 09/03/2019;

in revised form 23/03/2019)

Egypt. J. Phytopathol., Vol. 47, No. 1 (2019) 


\section{استحثثث المقاومة الجهازية لمرض العفن الفحمى فى

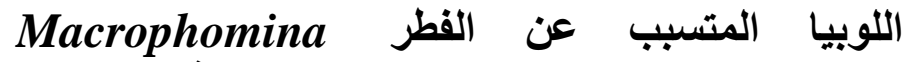 phaseolina}

منتصر فوزي عبد المنعم ،و مروي عبدالله محمود عطوة

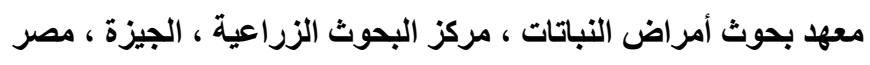

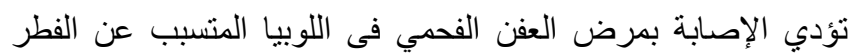

Macrophomina phaseolina

عزل ستة عثرعزلة من الفطر M. phaseolina من نباتات لوبيا مصابة القاتية

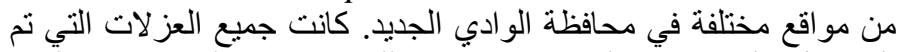

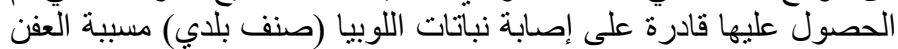

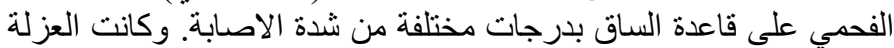

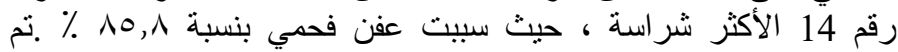

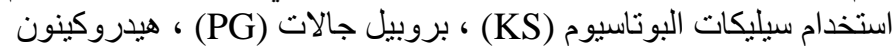

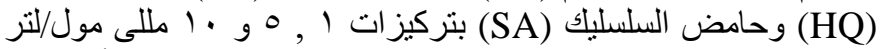

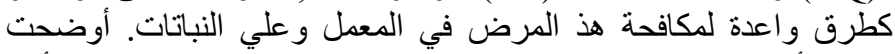

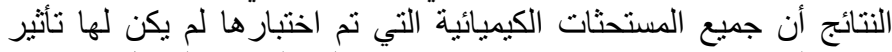

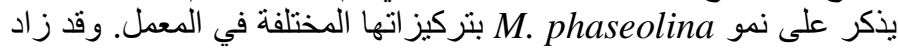

تثبيط نمو الفطر M. Phaseolina زيادة طفيفة عند زيادة تركيزات

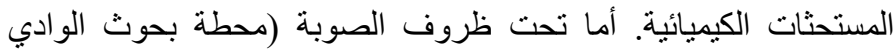

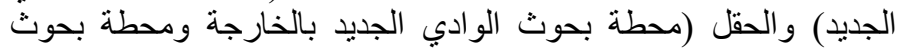

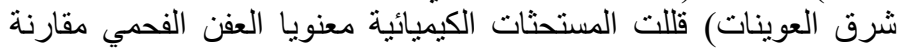

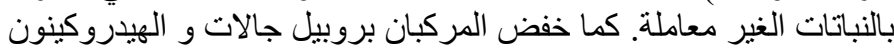

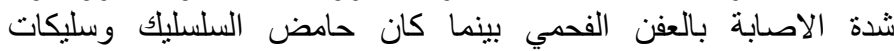
البوتاسيوم اقلهم تاثير ا. البهن

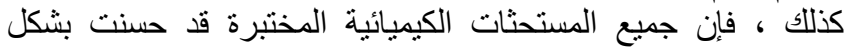

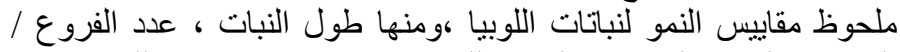

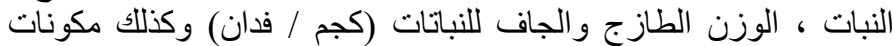

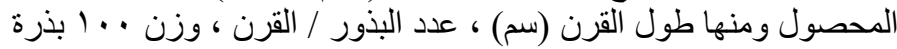

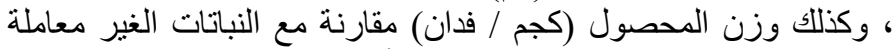

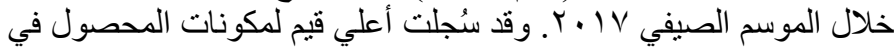

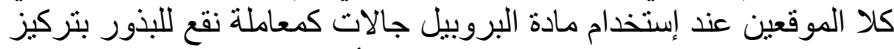

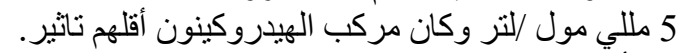

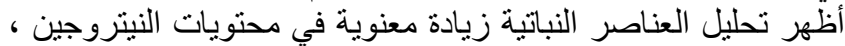

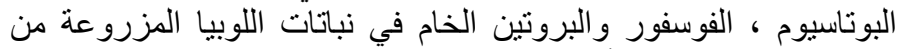

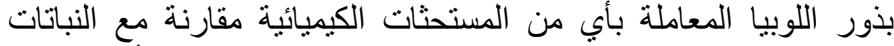

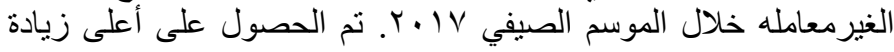


لهذه العناصر عند نقع بذور اللوبيا في حامض السلسليك باستثناء عنصر

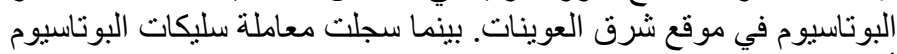

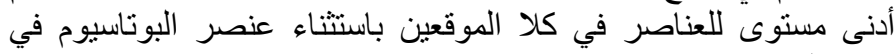

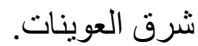

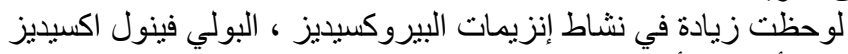

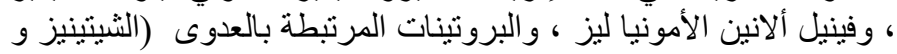

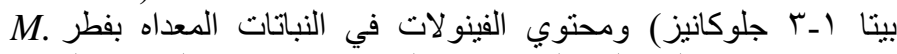
و و المعاملة بالمستحثات الكيميائية مقارنة بالنات بالنباتات المعداه

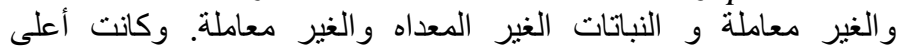

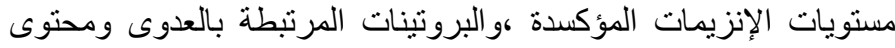
الفينول خلال جميع فترات الاختبار المحددة ناتجة من المعاملة بالبروبيل بالبيل

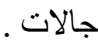

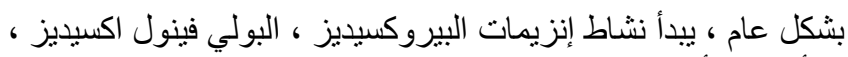

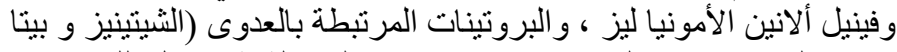

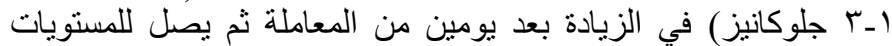

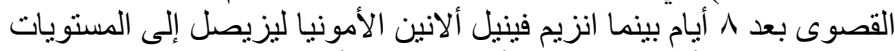

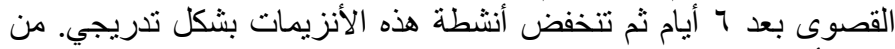

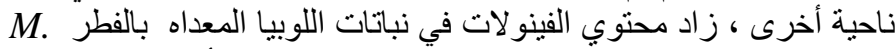
phaseolina

ل اللفينو لات بعد 6 أيام من المعاملة.

Egypt. J. Phytopathol., Vol. 47, No. 1 (2019) 